\title{
T-Cell Antigen CD7
}

National Cancer Institute

\section{Source}

National Cancer Institute. T-Cell Antigen CD7. NCI Thesaurus. Code C38935.

T-cell antigen CD7 (240 aa, $25 \mathrm{kDa}$ ) is encoded by the human CD7 gene. This protein plays a role in the development and function of lymphoid cells. 